\title{
TINGKAT KEPUASAN PELANGGAN \\ DARI KUALITAS JASA LAYANAN
}

\author{
Onny Juwono \\ Universitas Budi Luhur \\ Jln. Ciledug Raya Petukangan Utara Jakarta Selatan \\ onny_juwono2008@yahoo.com
}

\begin{abstract}
Recently, consumers become more critical. They criticize whenever they found the quality of service offered was not according to what had already been promised. On the other hand, quality of service became the sword of marketing program. Thus, these two elements go hand in hand to retain consumers. This research aims to answer some problems regarding quality of service of a photo developer retail outlet. Data gathered from consumers were analyzed by using validity, realibility and weighted mean to indicate the response of consumers towards all elements embeeded within the business. The research results showed that consumers found satisfied with the service given. However, the study suggested several steps to maintain customer satisfaction.
\end{abstract}

Keywords: consumer satisfaction, service quality, consumer

\begin{abstract}
ABSTRAK
Dewasa ini, konsumen menjadi lebih kritis. Mereka mengkritik setiap kali mereka menemukan kualitas layanan yang ditawarkan tidak sesuai dengan apa yang telah dijanjikan. Di sisi lain, kualitas pelayanan menjadi kunci program pemasaran. Dengan demikian, kedua elemen saling terkait dalam mempertahankan konsumen. Penelitian ini bertujuan untuk menjawab beberapa masalah tentang kualitas pelayanan outlet ritel studio foto. Data yang dikumpulkan dari konsumen dianalisis dengan menggunakan validitas, reliabilitas dan rata-rata tertimbang untuk menunjukkan respon konsumen terhadap semua elemen embeeded dalam bisnis. Hasil penelitian menunjukkan bahwa konsumen ditemukan puas dengan pelayanan yang diberikan. Namun, penelitian ini menyarankan beberapa langkah untuk mempertahankan kepuasan pelanggan.
\end{abstract}

Kata kunci: kepuasan konsumen, kualitas jasa, konsumen 


\section{PENDAHULUAN}

Kemajuan teknologi yang terus berkembang, misalnya teknologi komputer semakin memudahkan Studio Istimewa Foto Kebayoran Lama dapat mencetak foto sesuai keinginan pelanggan dan dapat mencetak foto dalam waktu 15 menit. Mengelola usaha foto studio membutuhkan pengetahuan, keterampilan, dan manajemen khusus seperti pengetahuan tentang photographer trik gambar serta keterampilan mengolah gambar. Selain itu, photographer juga harus benar-benar menguasai komputer, khususnya untuk program photoshop yang dapat merubah gambar menggunakan cara yang jeli. Komputer visual dapat menghasilkan foto yang dibentuk seindah warna aslinya.

Studio Istimewa Foto tidak hanya tempat mencetak foto dan memfoto lewat kamera digital yang saat ini dikategorikan modern, mencetak foto melalui hand phone (telepon genggam), tetapi juga memberikan layanan yang intensif bagi pelanggannya. Apabila pelanggan tidak puas terhadap layanannya seperti keterlambatan menerima hasil foto, foto yang tidak bagus (buram atau tidak jelas) hasil fotonya, maka dengan senang hati Studio Istimewa Foto akan mengganti semua biaya dan mengulang kembali pemotretan atau pencucian foto tanpa dipungut biaya apapun. Sebagai tindak lanjut untuk mencapai kepuasan pelanggan yang akan nantinya berdampak pada loyalitas jasa foto, maka Studio Istimewa Foto memberikan layanan kepada pelanggannya dengan memberikan hadiah gratis seperti tambahan hasil cetak, bingkai foto yang exlusive maupun hadiah berupa album foto dan lain sebagainya. Selain itu, dapat menerima panggilan foto album untuk pesta pernikahan, wisuda, seminar dan sebagainya. Berdasarkan hal tersebut, permasalahan dalam penelitian ini dirumuskan dengan kalimat sebagai berikut "Bagaimana tingkat kepuasan pelanggan dari kualitas jasa layanan yang diberikan Studio Istimewa Foto”. Penulis memilih topik ini dikarenakan ada beberapa maksud dan tujuan yang ingin dicapai, yaitu untuk mengetahui kualitas jasa layanan Studio Istimewa Foto Kebayoran Lama terhadap kepuasan para pelanggannya.

Konsep teoritis kepuasan-ketidakpuasan pelanggan dapat dikaji dari teori experientially affective feelings, expectancy disconfirmation theory, equity theory, attribution theory, dan teori ekonomi mikro (Ali Hasan, 2008:60). Pertama, experience affective feelings. Pendekatan experience affective (pengalaman $=$ perasaan) berpandangan bahwa tingkat kepuasan pelanggan dipengaruhi perasaan positif dan negatif yang diasosiasikan pelanggan dengan barang atau jasa tertentu setelah pembeliannya.

Kedua, expectancy disconfirmation theory. Pemakaian merek tertentu atau merek lainnya dalam kelas produk yang sama, pelanggan membentuk harapan mengenai kinerja seharusnya dari merek bersangkutan. Harapan atas kinerja dibandingkan kinerja aktual produk (yakni persepsi terhadap kualitas produk), ada 3 kemungkinan yang terjadi, yaitu (1) Apabila kualitas rendah dari harapan, yang terjadi adalah ketidakpuasan emosional (positive disconfirmation), (2) Apabila kinerja lebih besar dari pada harapan, maka yang terjadi adalah konfirmasi harapan (simple disconfirmation atau non satisfaction), dan (3) Apabila kinerja sama dengan harapan, maka yang terjadi adalah konfirmasi harapan (simple disconfirmation atau non satisfaction).

Ketiga, equity theory. Sejumlah peneliti berpendapat bahwa setiap orang menganalisis pertukaran antar dirinya (A) dan pihak lain (B) guna menentukan sejauh mana pertukaran tersebut adil atau fair. Equity theory beranggapan bahwa orang menganalisis rasio input dan hasilnya dengan rasio input dan hasil mitra pertukarannya. Jika orang merasa rasionya unvaroble dibandingkan lainnya dalam pertukaran tersebut, maka orang cenderung akan merasakan adanya ketidakadilan. Berdasarkan equity theory, perasaan tidak puas disebabkan keyakinan bahwa norma sosial telah dilanggar. Menurut teori ini, berlaku norma yang menegaskan bahwa setiap pihak dalam pertukaran harus mendapatkan perlakuan adil atau fair. Kepuasan terbentuk, yakni (1) Kepuasan terjadi bila rasio hasil dan input dalam pertukaran kurang lebih sama, (2) Ketidakpuasan terjadi apabila pelanggan meyakini bahwa 
rasio hasil input nya lebih jelek daripada perusahaan/penyedia jasa, (3) Kepuasan pelanggan terhadap transaksi tertentu dipengaruhi oleh perbandingan terhadap rasio dan input pelanggan lainnya, dan (4) Evaluasi terhadap keadilan keseluruhan (overall equity) dalam transaksi pembelian produk berpengaruh terhadap kepuasan/ketidakpuasan pelanggan.

Keempat, attribution theory. Attribution theory mengidentifikasi proses yang dilakukan seseorang dalam menentukan penyebab tindakan, orang lain dan objek tertentu. Atribusi yang dilakukan seseorang akan mempengaruhi purnabelinya terhadap produk tertentu karena atribusi memoderasi perasaan puas atau tidak puas. Ada 3 atribusi pelanggan terhadap kejadian atau peristiwa yang tidak diharapkan (Lovelock, Patterson dan Walker (1998) dalam Ali Hasan (2008:65)), yaitu (1) Causal attribution. Bila terjadi kesalahan, pelanggan segera menilai siapa yang patut disalahkan. Jika pelanggan menyimpulkan bahwa perusahaanlah yang salah, maka mereka akan sangat mungkin merasa tidak puas. Sebaliknya, apabila pelanggan membeberkan sebagai kesalahan pada diri mereka sendiri, maka ketidakpuasan mereka cenderung akan berkurang.; (2) Control attribution. Pelanggan menilai apakah ketidakpuasan berada dalam kendali pemasar atau tidak. Sebagai contoh, penumpang pesawat cenderung akan sangat tidak puas terhadap keterlambatan penerbangan bila mereka yakin bahwa penyebabnya adalah kelalaian pihak penyedia jasa dan bukan akibat gangguan cuaca yang berada diluar kendali mereka; (3) Stability attribution. Bila service encounter yang tidak memuaskan, maka pelanggan akan menilai apakah kejadian itu akan mungkin terulang lagi atau tidak. Jika pelanggan menilai bahwa kejadian itu cenderung terulang, maka ketidakpuasan pelanggan akan bertambah besar.

Kelima, teori ekonomi mikro. Dalam teori ekonomi, dasar yang digunakan oleh seorang konsumen dalam melakukan alokasi sumber daya yang langka adalah kondisi dimana perbandingan antara kegunaan marginal (marginal utility) dan harga masing-masing produk akan menjadi sama. Menurut Lovelock dan Wright (2005:96), kualitas jasa adalah evaluasi kognitif jangka panjang pelanggan terhadap penyerahan jasa suatu perusahaan. Dari kelima dimensi tersebut, keandalan yang telah terbukti menjadi inti dari kualitas jasa karena jasa yang tidak dapat diandalkan adalah jasa yang buruk walaupun ada atribut lainnya.

Menurut Parasuraman, Zeithaml dan Berry dalam Kotler \& Keller, dari alih bahasa Benyamin Molan (2007:55-56), ada 5 kesenjangan yang menyebabkan ketidakberhasilan penyerahan jasa, yaitu (1) Kesenjangan antara harapan konsumen dan persepsi manajemen, manajemen tidak selalu memahami dengan tepat apa yang diinginkan pelanggan. Pengurus rumah sakit mungkin berpikir bahwa pasien menginginkan makanan yang lebih baik, tetapi pasien mungkin lebih memikirkan daya tanggap perawat; (2) Kesenjangan antara persepsi manajemen dan pesifikasi mutu jasa. Manajemen mugkin memahami dengan tepat keinginan-keinginan pelanggan, tetapi tidak menetapkan standar kinerja. Pengurus rumah sakit mungkin meminta perawat memberikan layana yang "cepat" tanpa menguraikannya dengan sangat jelas; (3) Kesenjangan antara spesifikasi mutu jasa dan penyerahan jasa, karyawan mungkin kurang terlatih, tidak mampu atau tidak mau mematuhi standar, atau mereka mungkin dihadapkan pada standar yang saling bertentangan seperti menyediakan waktu untuk mendengarkan pelanggan dan melayani mereka dengan cepat; (4) Kesenjangan antara penyerahan jasa dan komunikasi eksternal, harapan-harapan konsumen dipengaruhi pernyataan-pernyataan yang dikeluarkan perwakilan dan iklan perusahaan. Jika brosur rumah sakit memperlihatkan kamar yang indah, tetapi pasien tiba dan menemukan kamar yang tampak murahan dan kotor, maka komunikasi eksternal telah melenceng jauh dari harapan pelanggan; (5) Kesenjangan antara persepsi jasa dan jasa yang diharapkan. Kesenjangan ini terjadi apabila konsumen tersebut memiliki persepsi yang keliru tentang mutu jasa tersebut. Dokter mungkin tetap mengunjungi pasien untuk menunjukkan kepeduliannya, tetapi pasien tersebut menafsirkan hal ini sebagai indikasi bahwa ada sesuatu yang benar-benar tidak beres.

Zeithaml et al., dalam Husein Umar (2005:38-39) mengemukakan 5 dimensi dalam menentukan kualitas jasa, yaitu (1) Reliability, yaitu kemampuan untuk memberikan pelayanan yang 
sesuai dengan janji yang ditawarkan; (2) Responsiveness, yaitu respon atau kesigapan karyawan dalam membantu pelanggan dan memberikan pelayanan yang cepat dan taggap, yang meliputi kesigapan karyawan dalam melayani pelanggan, kecepatan karyawan dalam menangani transaksi, dan penanganan keluhan pelanggan/pasien; (3) Assurance, meliputi kemampuan karyawan atas pengetahuan terhadap produk secara tepat, kualitas keramahtamahan, perhatian dan kesopanan dalam memberikan pelayanan, keterampilan dalam memberikan informasi, kemampuan dalam memberikan keamanan didalam memanfaatkan jasa yang ditawarkan dan kemampuan dalam menanamkan kepercayaan pelanggan terhadap perusahaan; (4) Emphaty, yaitu perhatian secara individual yang diberikan perusahaan kepada pelanggan seperti kemudahan untuk menghubungi perusahaan, kemampuan karyawan untuk berkomunikasi dengan pelanggan dan usaha perusahaan untuk memahami keinginan dan kebutuhan pelanggannya; (5) Tangibles, meliputi penampilan fasilitas fisik seperi gedung dan ruangan front office, tersedianya tempat parkir, kebersihan, kerapihan dan kenyamanan ruangan, kelengkapan peralatan komunikasi dan penampilan karyawan.

\section{METODE PENELITIAN}

\section{Operasionalisasi Variabel}

\begin{tabular}{|c|c|c|}
\hline Variabel & Sub Variabel & Indikator \\
\hline \multirow[t]{5}{*}{$\begin{array}{l}\text { Kepuasan Ali Hasan } \\
\text { (2008:57) }\end{array}$} & Nommitive deficit : & $\begin{array}{l}\text { Layanan di Studio Istimewa Foto dibandingkan dengan } \\
\text { studio foto lainnya } \\
\text { Hasil cuci cetak di studio Istimewa Foto dibandingkan } \\
\text { dengan studio foto lainnya }\end{array}$ \\
\hline & Equity: & $\begin{array}{l}\text { Hasil layanan sehingga konsumen merasa tidak } \\
\text { dirugikan }\end{array}$ \\
\hline & Normative standar : & Hasil cuci cetak sudah memenuhi standar pelanggan \\
\hline & Procedural fairness : & $\begin{array}{l}\text { Perlakuan karyawan sudah secara adil dan tidak } \\
\text { membeda-bedakan pelanggan }\end{array}$ \\
\hline & Attributional : & $\begin{array}{l}\text { Solusi karyawan bila terjadi kesalahan atau } \\
\text { pembatalan cuci cetak }\end{array}$ \\
\hline \multirow[t]{6}{*}{$\begin{array}{l}\text { Kualitas Jasa Layanan } \\
\text { Fandy Tjiptono, } \\
\text { Gregorius Chandra, Dadi } \\
\text { Adriana(2008:68-69) }\end{array}$} & Reliabilitas : & $\begin{array}{l}\text { Kecepatan karyawan dalam menangani layanan } \\
\text { Ketepatan waktu penyelesaian cuci cetak foto } \\
\text { Harga yang ditawarkan di Studio Istimewa Foto }\end{array}$ \\
\hline & Responsivitas : & Penanganan keluhan konsumen \\
\hline & Jaminan (assurance) : & $\begin{array}{l}\text { Kemampuan karyawan dalam pengeditan foto } \\
\text { Keramahan dan kesopanan karyawan } \\
\text { Keyakinan karyawan akan hasil foto yang dicetak }\end{array}$ \\
\hline & Empati : & $\begin{array}{l}\text { Kemudahan dalam menjalin hubungan } \\
\text { Karyawan selalu memberikan jawaban yang jelas dan } \\
\text { kekeluargaan } \\
\text { Memahami keinginan konsumen }\end{array}$ \\
\hline & Bukti fisik (tangibles) : & $\begin{array}{l}\text { Bentuk fisik bangunan } \\
\text { Kelengkapan peralatan took } \\
\text { Kebersihan ruang }\end{array}$ \\
\hline & & Tempat parkir yang disediakan \\
\hline
\end{tabular}


Dalam penelitian ini, jumlah sampel yang digunakan sebanyak 90 orang responden, yang merupakan pelanggan di Studio Istimewa Foto, yang diperoleh dengan cara menyebarkan daftar pertanyaan atau kuesioner untuk memperoleh informasi secara langsung dari responden sebagai objek penelitian.

\section{HASIL DAN PEMBAHASAN}

Dari hasil pengolahan data yang dihasilkan lewat wawancara kepada seluruh pengguna jasa objek riset, ditemukan sebagai berikut:

Tabel 1 Kepuasan Pelanggan

\begin{tabular}{clc}
\hline No. & $\begin{array}{l}\text { Kuesioner Berdasarkan Kepuasan } \\
\text { Pelanggan }\end{array}$ & $\begin{array}{l}\text { Rata-rata Hasil } \\
\text { Kuesioner }\end{array}$ \\
\hline 1. & $\begin{array}{l}\text { Layanan Studio Istimewa Foto dibandingkan } \\
\text { dengan studio foto lainnya }\end{array}$ & 3,97 \\
2. & $\begin{array}{l}\text { Hasil cuci cetak Studio Istimewa Foto } \\
\text { dibandingkan dengan studio foto lainnya }\end{array}$ & 4,14 \\
3. & $\begin{array}{l}\text { Hasil layanan sehingga konsumen merasa } \\
\text { tidak dirugikan }\end{array}$ & 3,88 \\
4. & $\begin{array}{l}\text { Hasil cuci cetak sudah memenuhi standar } \\
\text { pelanggan }\end{array}$ & 3,94 \\
5. & $\begin{array}{l}\text { Karyawan sudah secara adil dan tidak } \\
\text { membeda-bedakan pelanggan }\end{array}$ & 3,93 \\
6. & $\begin{array}{l}\text { Solusi karyawan bila terjadi kesalahan atau } \\
\text { pembatalan cuci cetak }\end{array}$ & 3,71 \\
& Total & 23,57 \\
\hline
\end{tabular}

Sumber: Data diolah sendiri

$$
\bar{X} W=\frac{23,78}{6}=3,92 \text { Skala Likert }
$$

Dari hasil penelitian pada Tabel 1, dapat disimpulkan bahwa kuesioner berdasarkan kepuasan pelanggan Studio Istimewa Foto dengan besaran 3,92 Skala Likert yang terletak pada rentang skala Puas. Jadi, responden puas dengan layanan yang diberikan Studio Istimewa Foto. 
Tabel 2 Kualitas Jasa Layanan

\begin{tabular}{|c|c|c|}
\hline No. & Kuesioner Berdasarkan Kualitas Jasa Layanan & $\begin{array}{c}\text { Rata-rata Hasil } \\
\text { Kuesioner }\end{array}$ \\
\hline 1. & Kecepatan karyawan dalam menangani layanan & 4,04 \\
\hline 2. & Ketepatan waktu penyelesaian cuci cetak foto & 3,67 \\
\hline 3. & Harga yang ditawarkan & 3,78 \\
\hline 4. & Penangana keluhan konsumen & 3,68 \\
\hline 5. & Kemampuan karyawan dalam pengeditan foto & 4,17 \\
\hline 6. & Keramahan dan kesopanan karyawan & 3,94 \\
\hline 7. & Keyakinan karyawan akan hasil foto yang dicetak & 4,11 \\
\hline 8. & Kemudahan dalam menjalin hubungan & 3,96 \\
\hline 9. & $\begin{array}{l}\text { Karyawan selelu memberikan jawaban yang jelas dan } \\
\text { kekeluargaan }\end{array}$ & 3,95 \\
\hline 10. & Memahami keinginan konsumen & 3,81 \\
\hline 11. & Bentuk fisik bangunan & 3,48 \\
\hline 12. & Kelengkapan peralatan toko & 4,25 \\
\hline 13. & Penampilan dan cepat tanggap karyawan & 3,76 \\
\hline \multirow[t]{2}{*}{14.} & Kebersihan ruang & 3,24 \\
\hline & Total & 53,84 \\
\hline
\end{tabular}

Sumber: Data diolah sendiri

$$
\bar{X} W=\frac{53,84}{14}=3,84 \text { Skala Likert }
$$

Dari hasil penelitian pada Tabel 2, dapat disimpulkan bahwa kuesioner berdasarkan kualitas jasa layanan Studio Istimewa Foto dengan besaran 3,84 Skala Likert yang terletak pada rentang skala Puas. Jadi, responden puas dengan kualitas jasa layanan yang diberikan Studio Istimewa Foto.

$$
\bar{X}=\frac{77,41}{20}=3,87 \text { Skala Likert }
$$

Kesimpulan berdasarkan analisis Rata-rata Tertimbang, hasil tertinggi dapat dilihat pada kuesioner kelengkapan peralatan toko sebesar 4,25 skala Likert, yang berarti bahwa rata-rata responden menjawab "sangat puas" dengan kelengkapan peralatan toko yang tersedia di Studio Istimewa Foto. Sedangkan hasil terendah pada kuesioner kebersihan ruang sebesar 3,24 skala Likert yang berarti rata-rata responden menjawab "netral” dengan kebersihan ruang Studio Istimewa Foto. Berdasarkan seluruh pertanyaan (20 pertanyaan) yang seluruhnya meliputi kepuasan pelanggan dari kualitas jasa layanan, didapatkan analisis rata-rata tertimbang sebesar 3,87 Skala Likert, yang berarti bahwa responden di Studio Istimewa Foto, Kebayoran Lama bersikap "puas” bahwa tingkat kepuasan pelanggan terletak pada kualitas jasa layanan yang diberikan oleh Studio Istimewa Foto.

\section{SIMPULAN}

Kesimpulan berdasarkan Analisis Rata-rata Tertimbang, hasil tertinggi dapat dilihat pada kuesioner kelengkapan peralatan toko sebesar 4,25 skala Likert, yang berarti bahwa rata-rata responden menjawab "sangat puas" dengan kelengkapan peralatan toko yang tersedia di Studio Istimewa Foto. Sedangkan hasil terendah terdapat pada kuesioner kebersihan ruang sebesar 3,24 skala Likert yang berarti rata-rata responden menjawab "netral" dengan kebersihan ruang Studio Istimewa Foto. Berdasarkan seluruh pertanyaan (20 pertanyaan) yang seluruhnya meliputi kepuasan pelanggan dari kualitas jasa layanan, didapatkan analisis rata-rata tertimbang sebesar 3,87 Skala Likert, yang 
berarti para responden di Studio Istimewa Foto, Kebayoran Lama bersikap "puas" bahwa tingkat kepuasan pelanggan terletak pada kualitas jasa layanan yang diberikan oleh Studio Istimewa Foto. Berdasarkan hasil kesimpulan di atas, penulis dapat mengemukakan beberapa saran yang dapat bermanfaat bagi Studio Istimewa Foto, yaitu (1) Hendaknya Studio Istimewa Foto mempertahankan kualitas produk dan layanan yang diberikan kepada setiap pelanggannya dengan cara menjaga kualitas hasil cetakan foto agar lebih bagus sehingga Studio Istimewa Foto mampu lebih banyak mendapat pelanggannya untuk tidak berpaling ke studio foto lainnya; (2) Meningkatkan kebersihan dilingkungan Studio Istimewa Foto supaya pelanggan merasa lebih nyaman dan leluasa berada di sana, misalnya menyediakan tempat sampah organik dan anorganik; (3) Meningkatkan kedisiplinan terhadap karyawannya sehingga karyawan mampu menghadapi pesaing diluar dan bisa menjaga nama baik Studio Istimewa Foto di mata para pelanggan, misalnya karyawan tepat waktu, berpakaian rapi, dan sopan santun terhadap pelanggan; (4) Mempertahankan kelengkapan peralatan foto dengan cara memelihara dan melakukan perawatan secara rutin terhadap peralatan tersebut. Studio Istimewa Foto juga harus selalu memperbaharui peralatan yang ada agar selalu mengikuti perkembangan teknologi di dunia fotografi sehingga dapat menjaga dan terus meningkatkan kepuasan pelanggan; dan (5) Memberikan suvenir/merchandise bagi konsumen Studio Istimewa Foto apabila secara rutin datang untuk menggunakan jasa dari Studio Istimewa Foto, misalnya konsumen datang 11 kali ke Studio Istimewa Foto diberikan souvenir, dengan syarat membawa kuitansi/bukti pembayaran sebelumnya.

\section{DAFTAR PUSTAKA}

Hasan, A. (2008). Marketing, Yogyakarta: Azza Grafika.

Kotler, P., dan Keller, K.L. (2007). Manajemen pemasaran, edisi kedua belas. Dialih bahasakan oleh Benyamin Molan, Jakarta: PT Indeks.

Lovelock, C., dan Lauren K. Wright (2005). Manajemen pemasaran jasa, Jakarta: PT Indeks.

Umar, H. (2005). Riset pemasaran dan perilaku konsumen, cetakan keempat, Jakarta: PT Gramedia Pustaka Utama. 